\title{
Hantavirus pulmonary syndrome in Texas: An update covering years 1993 through 2016
}

\author{
Kenneth Nugent MD, James L. Alexander DVM, MPVM
}

\begin{abstract}
Background: Hantavirus pulmonary syndrome continues to occur sporadically in Texas. Rivers and coworkers published a summary of cases identified between 1993 and 2006. This report updates the information on Hantavirus pulmonary syndrome cases identified between 2007 and 2016 to determine whether or not there are differences in clinical presentation or outcomes.

Methods: The Texas Department of State Health Services collects information on the Hantavirus pulmonary syndrome using the Centers for Disease Control and Prevention, Special Pathogens Branch case report form (OMB No.0920-0090). This form collects demographic information, patient exposure information, timeline, clinical information, laboratory tests, and outcomes.

Results: This report summarizes information from the Texas Department of State Health Services on 45 cases with Hantavirus pulmonary syndrome reported between 1993 and 2016. Most patients were men and were non-Hispanic white or Hispanics. Laboratory tests revealed leukocytosis, an increased percentage of neutrophil bands, hemoconcentration, thrombocytopenia, and variable acute kidney injury. The case fatality rate was $31 \%$. Since 2007 , the case fatality rate has decreased. The cases remain clustered in the Northwest Texas (Public Health Region 1).

Summary: Hantavirus pulmonary syndrome continues to occur sporadically in Texas. The clinical presentation has not changed since 1993, but outcomes appear to be improving. Public health efforts need to focus on public education to reduce the risk of exposure.
\end{abstract}

Keywords: Hantavirus pulmonary syndrome, Texas, laboratory tests, outcomes

\section{INTRODUCTION}

The initial report on Hantavirus pulmonary syndrome in the United States included 17 patients from New Mexico, Arizona, and Colorado; 15 patients developed acute pulmonary edema, and 13 patients died. ${ }^{1}$ The initial 100 cases included 56 patients from the Four Corners region (New Mexico, Arizona, Utah, Nevada) in the western United States. ${ }^{2}$ Thirty-five percent of these patients were Native Americans. Rivers

Corresponding author: Kenneth Nugent Contact Information: Kenneth.nugent@ttuhsc.edu DOI: $10.12746 /$ swrccc.v6i22.436 and coworkers summarized information on 28 cases identified in Texas between 1993 and 2006. ${ }^{3}$ They noted a change in demographics and a reduction in case fatality. Patients with Hantavirus pulmonary syndrome usually develop acute respiratory failure requiring mechanical ventilation, hemoconcentration, thrombocytopenia, and acute kidney injury. The epidemiology involves exposure to rodents or rodent excretions which contain the virus. A recent article summarized the demographics of all reported cases in the United States in the years of 1993-2015 but did not provide clinical data. ${ }^{4}$ This report summarizes demographic and clinical information obtained from the Texas Department of State Health Services on 45 cases reported between 1993 and 2016. 


\section{Methods}

The Texas Department of State Health Services collects information on the Hantavirus pulmonary syndrome using the Centers for Disease Control and Prevention, Special Pathogens Branch case report form (OMB No.0920-0090). This form collects patient demographics, patient exposure information, timeline, clinical information, laboratory tests, viral studies, and outcomes. We retrospectively reviewed data for 45 cases obtained from the Texas Department of State Health Services, consisting of 44 case report forms, and a spreadsheet summarizing data for one patient for whom the form was missing. All personal identifying information was redacted from these forms. In addition, not all reports included a complete summary of information relevant to the particular patient. However, the State Department of Health Services indicated that these were confirmed cases based on information on the form and other information which was not available to these investigators. This study was approved by the Texas Tech University Health Sciences Center Institutional Review Board and the Texas Department of State Health Services Institutional Review Board.

\section{RESULTS}

This study included 45 patients with Hantavirus pulmonary syndrome identified in Texas between 1993 and 2016. The median age was 32 years (25-50 interquartile range); 31 patients were male (68.9\%). The ethnic distribution included 23 white non-Hispanic patients, 18 Hispanic patients, one black patient, and three patients with no information. Thirty-two cases reported rodent exposure in the environment, five denied exposure, six had unknown exposure, and one reported possible exposure. Detailed records were missing from one case. Thirty-one cases reported the deer mouse (Peromyscus maniculatus) as the source of exposure and three cases, involving the Bayou virus in southeastern Texas, were associated with marsh rice rats (Oryzomis palustris). Thirty-four cases were associated with the Sin Nombre species (SNV), five were associated with Bayou or Bayoulike species, and six had inadequate information for

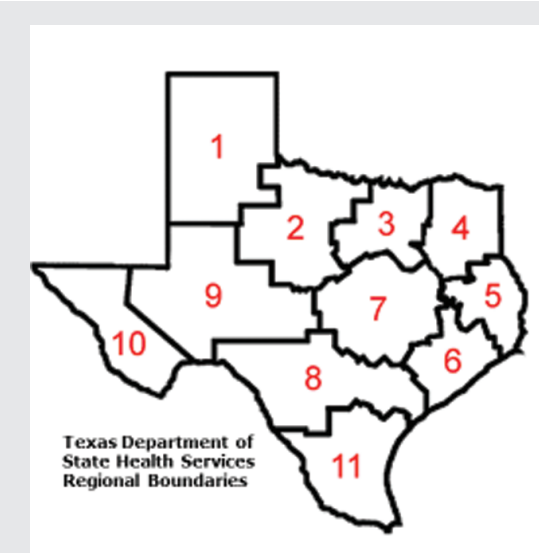

\begin{tabular}{ll}
\hline Region & Cases \\
\hline 1 & 23 \\
2 & 1 \\
3 & 2 \\
4 & 0 \\
5 & 5 \\
6 & 4 \\
7 & 1 \\
8 & 1 \\
9 & 4 \\
10 & 2 \\
11 & 2
\end{tabular}

Figure 1. Distribution of cases in the State Health Service Regions in Texas.

classification. Twenty-three (51\%) cases came from Health Services Region (HSR) 1 (Northwest Texas). Nine cases $(20 \%)$ were recorded in the southeastern area of the state (HSR 5/6S); the remainder were spread across the rest of the state with the exception of the far northeastern region (HSR 4) which has had no cases recorded (Figure 1-Texas HSRs). Cases have occurred in every month; May and August had more cases as shown in the seasonal distribution plotted in Figure 2. Laboratory and clinical information are reported in the Table. The WBC, percent bands, hematocrit, platelet counts, and creatinine levels were similar in the two patient cohorts reported

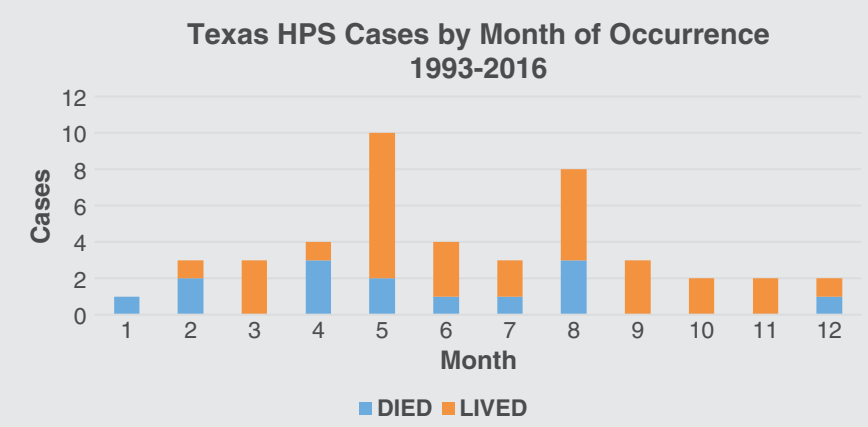

Figure 2. Seasonal distribution of cases from 19932016. 
Table: Demographic, laboratory, and clinical details for Hantavirus cases

\begin{tabular}{|c|c|c|c|}
\hline Time period for Hanta case presentation & $1993-2016(\mathrm{~N}=45)$ & $1993-2006(\mathrm{~N}=33)$ & $2007-2016(\mathrm{~N}=12)$ \\
\hline \multicolumn{4}{|l|}{ Demographics } \\
\hline $\begin{array}{l}\text { Age, years, median } \\
\text { Interquartile range }\end{array}$ & $\begin{array}{l}32 \\
25,50 \\
N=45\end{array}$ & $\begin{array}{l}31 \\
25,50 \\
N=33\end{array}$ & $\begin{array}{l}31.5 \\
25,50 \\
\mathrm{~N}=12\end{array}$ \\
\hline Gender, $\%$ male & $69.0(31 / 45)$ & $63.6(21 / 33)$ & $83.3(10 / 12)$ \\
\hline Ethnicity & $\begin{array}{l}23 \text { White, non-Hispanic } \\
18 \text { Hispanic } \\
1 \text { Black, } 3 \mathrm{NR} \\
\mathrm{N}=45\end{array}$ & $\begin{array}{l}16 \text { White, non-Hispanic } \\
13 \text { Hispanic } \\
1 \text { Black, } 3 \text { NR } \\
N=33\end{array}$ & $\begin{array}{l}7 \text { White non-Hispanic } \\
5 \text { Hispanic } \\
\mathrm{N}=12\end{array}$ \\
\hline \multicolumn{4}{|l|}{ Laboratory } \\
\hline $\begin{array}{l}\text { WBC, } 10^{9} / \mathrm{L} \text {, median } \\
\text { Interquartile range }\end{array}$ & $\begin{array}{l}17.8 \\
9.9,28.3 \\
\mathrm{~N}=40\end{array}$ & $\begin{array}{l}14.6 \\
9.6,28.6 \\
N=29\end{array}$ & $\begin{array}{l}17.6 \\
9.3,27.4 \\
N=11\end{array}$ \\
\hline $\begin{array}{l}\text { Bands, } \% \text {, median } \\
\text { Interquartile range }\end{array}$ & $\begin{array}{l}17.5 \\
12.0,36 \\
\mathrm{~N}=33\end{array}$ & $\begin{array}{l}17.0 \\
12.0,36.0 \\
\mathrm{~N}=27\end{array}$ & $\begin{array}{l}13.5 \\
7.0,25.0 \\
N=6\end{array}$ \\
\hline $\begin{array}{l}\text { Hct, } \% \text {, median } \\
\text { Interquartile range }\end{array}$ & $\begin{array}{l}51.2 \\
43.3,55.7 \\
\mathrm{~N}=38\end{array}$ & $\begin{array}{l}52.7 \\
45.4,55.5 \\
\mathrm{~N}=29\end{array}$ & $\begin{array}{l}45.5 \\
42.6,52.7 \\
N=9\end{array}$ \\
\hline $\begin{array}{l}\text { Platelet, } 10^{9} / \mathrm{L} \text {, median } \\
\text { Interquartile range }\end{array}$ & $\begin{array}{l}54.5 \\
39.5,84.5 \\
\mathrm{~N}=38 \\
\end{array}$ & $\begin{array}{l}55 \\
34.0,81.0 \\
\mathrm{~N}=29 \\
\end{array}$ & $\begin{array}{l}54 \\
43.5,93.0 \\
N=9\end{array}$ \\
\hline $\begin{array}{l}\mathrm{Cr}, \mathrm{mg} / \mathrm{dl} \text {, median } \\
\text { Interquartile range }\end{array}$ & $\begin{array}{l}1.6 \\
1.0,2.1 \\
\mathrm{~N}=35\end{array}$ & $\begin{array}{l}1.7 \\
1.0,2.1 \\
\mathrm{~N}=26\end{array}$ & $\begin{array}{l}1.1 \\
1.0,1.7 \\
\mathrm{~N}=9\end{array}$ \\
\hline \multicolumn{4}{|l|}{ Clinical information } \\
\hline Fever & $36 \mathrm{Y}, 6 \mathrm{~N}, 3 \mathrm{NR}$ & $26 \mathrm{Y}, 4 \mathrm{~N}, 3 \mathrm{NR}$ & $10 \mathrm{Y}, 2 \mathrm{~N}$ \\
\hline Chest x-ray & $37 \mathrm{Y}, 4 \mathrm{~N}, 4 \mathrm{NR}$ & $27 \mathrm{Y}, 4 \mathrm{~N}, 2 \mathrm{NR}$ & $10 \mathrm{Y}, 2 \mathrm{NR}$ \\
\hline Ventilator & $30 \mathrm{Y}, 13 \mathrm{~N}, 2 \mathrm{NR}$ & $23 \mathrm{Y}, 8 \mathrm{~N}, 2 \mathrm{NR}$ & $7 \mathrm{Y}, 5 \mathrm{~N}$ \\
\hline Outcome & $31 \mathrm{~A}, 14 \mathrm{D}$ & $20 \mathrm{~A}, 13 \mathrm{D}$ & $11 \mathrm{~A}, 1 \mathrm{D}^{*}$ \\
\hline
\end{tabular}

NR-not reported, Y-yes, N-no, A-alive, D-dead, WBC-white blood count, Hct-hematocrit, Cr-creatinine.

$* \mathrm{P}=0.07$, Difference in outcomes between 1993-2006 period and 2007-2017 period, by Fisher exact test.

between 1993-2006 and 2007-2016. Most patients (42) required supplemental oxygen, and 30 required ventilator support. Fourteen patients $(31.1 \%)$ died; the last fatality was in 2007 . The case fatality rate from 2007 to 2016 was lower than the rate in 19932006 (Fisher exact test, $p=0.07$ )

\section{Discussion}

Six hundred and sixty-two cases of Hantavirus pulmonary syndrome have occurred in the United States since 1993. ${ }^{4}$ Approximately two cases of Hantavirus pulmonary syndrome per year have occurred in 
Texas since 1993. Most patients were young white men in Northwest Texas and had leukocytosis $(75 \%$ of patients), an increased percent bands (91\%), elevated hematocrits $(68 \%)$, reduced platelet counts $(92 \%)$, elevated creatinine (53\%), fever, and abnormal chest $\mathrm{x}$-rays consistent with interstitial/alveolar edema. They often required mechanical ventilation, and the case fatality exceeded $31 \%$. The case fatality rate for SNV was $38 \%$; the rate for the Bayou/ Bayou-like viruses was $20 \%$. In the initial report from the United States the mean age was 32 years, $61 \%$ were women, and $72 \%$ were Native Americans. ${ }^{1}$ These patients presented with tachypnea, tachycardia, and hypotension. Laboratory results included leukocytosis, increased hematocrits, thrombocytopenia, and normal creatinine levels. The cohort of patients from Texas had a higher percentage of men $(69 \%)$ than the initial study in 1994 and did not include any Native Americans. The clinical presentation and laboratory results have not changed, but the outcomes are better with lower case fatality rates. Rivers et al reported information on 28 cases identified in Texas between 1993 and 2006. ${ }^{3}$ The case fatality rate in the current series is slightly lower; this may reflect better supportive care or more reports of "mild" cases. The majority of cases continue to occur in the Texas Panhandle and in Southeast Texas.

These infections develop after exposure to rodents, especially deer mice, and rodent excretions. ${ }^{5}$ However, important details about the pathogenesis of these infections remain incomplete, and treatment information is quite limited. Brocato and coworkers have developed a hamster model of Hantavirus pulmonary syndrome using immunosuppression with dexamethasone and cyclophosphamide. ${ }^{6}$ Immunosuppressed animals developed clinical signs of Hantavirus pulmonary syndrome, had pulmonary edema on histology, and had viral antigen present throughout the pulmonary endothelium. Hantavirus specific neutralizing polyclonal antibody administered five days after infection provided significant protection against this disease. Safronetz et al have developed a model for Hantavirus infection in rhesus macaques. ${ }^{7}$ These animals rapidly develop respiratory distress and have an immune response preferentially localized to the pulmonary interstitium despite having widespread endothelial infection. These models provide the opportunity to study antiviral drugs and antisera in controlled studies. ${ }^{8,9}$ This information is essential to provide specific therapy for this sporadic disease.

We also need more complete information on the seasonal distribution of these infections, the relationship with rodent population density, rodent susceptibility to infection, and viral titers in rodents. Rodent population densities vary across geographic regions and across seasons. ${ }^{10}$ The Centers for Disease Control and Prevention recently reported that 17 patients in seven states have been infected with the Seoul virus following exposure to infected rats shipped from two facilities in Illinois and Wisconsin (Multi-state outbreak of Seoul virus. www.cdc. gov/hantavirus/outbreaks/seoul-virus/index.html, accessed 4-28-2017). The Seoul virus causes a different clinical syndrome (hemorrhagic fever with renal syndrome); there have been no reports of Hantavirus pulmonary syndrome acquired through the shipment of pet rodents. However, the potential for widespread distribution of infected rodents throughout the United States greatly complicates epidemiologic studies of Hantavirus pulmonary syndrome, if this were to occur.

In summary, Hantavirus pulmonary syndrome continues to occur at a low and sporadic rate in Texas. There are no consistent factors known to predispose humans to severe disease; it is unknown whether severe presentations represent overwhelming viral infections, increased viral virulence, defective host defense responses, or exuberant pro-inflammatory host defense responses causing multiorgan failure. There is no definitive treatment other than supportive care; our results suggest that outcomes have improved over the last 10 years. Animal models provide the potential to identify specific treatment based on immunoglobulin administration or viral drugs. Most clinicians will never encounter a patient with this syndrome. Since it occurs more frequently in certain regions, this information provides the basis for health professional and public health education with a focus on prevention. 
Article citation: Alexander JL, Nugent K. Hantavirus pulmonary syndrome in Texas: an update covering years 1993 through 2016. Southwest Respiratory and Critical Care Chronicles 2018;6(22):16-20.

From: The Texas Department of State Health Services in Canyon, TX (JLA); Department of Internal Medicine at Texas Tech University Health Sciences Center, Lubbock, TX (KN)

Submitted: $12 / 10 / 2017$

Accepted: $12 / 24 / 2017$

Reviewers: Ronald Warner DVM, PhD

Conflicts of interest: none

\section{REFERENCES}

1. Duchin JS, Koster FT, Peters CJ, et al. Hantavirus pulmonary syndrome: a clinical description of 17 patients with a newly recognized disease. The Hantavirus Study Group. N Engl J Med 1994;330:949-55.

2. Khan AS, Khabbaz RF, Armstrong LR, et al. Hantavirus pulmonary syndrome: the first 100 US cases. J Infectious dDisease 1996;173:1297-303.

3. Rivers MN, Alexander JL, Rohde RE, Pierce JR. Hantavirus pulmonary syndrome in Texas: 1993-2006. South Med J 2009;102:36-41.
4. de St. Maurice A, Ervin E, et al. Exposure chracteristics of Hantavirus pulmonary syndrome patients, United States, 1993-2015. Emerg Infect Dis 2017;733-739.

5. Calisher CH, Mills JN, Root JJ, Doty JB, Beaty BJ. The relative abundance of deer mice with antibody to Sin Nombre virus corresponds to the occurrence of hantavirus pulmonary syndrome in nearby humans. Vector Borne Zoonotic Dis 2011;11:577-82.

6. Brocato RL, Hammerbeck CD, Bell TM, Wells JB, Queen LA, Hooper JW. A lethal disease model for hantavirus pulmonary syndrome in immunosuppressed Syrian hamsters infected with Sin Nombre virus. J Virol 2014;88: 811-9.

7. Safronetz D, Prescott J, Feldmann F, et al. Pathophysiology of hantavirus pulmonary syndrome in rhesus macaques. Proc Natl Acad Sci U S A 2014;111:7114-9.

8. Safronetz D, Falzarano D, Scott DP, Furuta Y, Feldmann $\mathrm{H}$, Gowen BB. Antiviral efficacy of favipiravir against two prominent etiological agents of hantavirus pulmonary syndrome. Antimicrob Agents Chemother 2013;57: 4673-80.

9. Haese N, Brocato RL, Henderson T, et al. Antiviral Biologic Produced in DNA Vaccine/Goose Platform Protects Hamsters Against Hantavirus Pulmonary Syndrome When Administered Post-exposure. PLoS Negl Trop Dis 2015; 9:e0003803.

10. Calisher CH, Sweeney W, Mills JN, Beaty BJ. Natural history of Sin Nombre virus in western Colorado. Emerg Infect Dis 1999;5:126-34. 